\title{
Use of cacti as heat sources by thermoregulating Mabuya agilis (Raddi) and Mabuya macrorhyncha Hoge (Lacertília, Scincidae) in two restinga habitats in southeastern Brazil
}

\author{
Davor Vrcibradic ${ }^{1,2}$ \\ Carlos Frederico Duarte Rocha ${ }^{1,3}$
}

\begin{abstract}
Lizards may benefit from gain of heat from contact with the substrate via conduction. In this study, evidence that the lizards Mabuy'a agilis (Raddi, 1823) and Mabuy'a macrorhyncha Hoge, 1946 (Scincidae) inhabiting two restinga habitats in southeastern Brazil (Grussaí, Rio de Janeiro and Praia das Neves, Espírito Santo), may shift microhabitat preferences along the day, and that such shifts may be related to the use of cacti surfaces as direct sources of heat is presented. For both species, body temperature $\left(T_{h}\right)$ was always significantly correlated $(p<0,05)$ with air temperature $\left(\mathrm{T}_{\mathrm{a}}\right)$. $\mathrm{T}_{\mathrm{h}}$ was significantly correlated $(\mathrm{p}<0,05)$ with substrate temperature $\left(\mathrm{T}_{\mathrm{s}}\right)$ for $M$ agilis collected on cacti, but not for specimens collected on the ground. For $M$. macrorhyncha collected on cacti, both $\mathrm{T}_{\mathrm{a}}$ and $\mathrm{T}_{\mathrm{s}}$ were more important in conjunction than separately, in explaining lizard $T_{b}$. Use of cacti as perches by $M$. agilis was more frequent during late afternoon when environmental temperatures are declining, but such a trend was not evident for M. macrorhyncha. We suggest that the use of cacti as direct heat sources may be more evident in the ground-dwelling $M$. agilis than in the scansorial M. macrorhyncha.

KEY WORDS. Mabuy'a, lizard, thermoregulation, cacti, heat gain by conduction, restinga habitat, Southeast Brazil
\end{abstract}

Microhabitat use may be linked to thermoregulatory behavior in lizards, since different microclimates may be availablc at different microhabitats; nevertheless, microclimatic characteristics of a given microhabitat may vary in time and space (c.g. HEATWOLE \& TAYLOR 1987). Altitudinal, scasonal and/or hourly variations in microhabitat use patterns by lizards, related to thermoregulatory behavior, have been reported in a number of studies (e.g. RAND \& RAND 1966; Heatwole 1970; Huey et al. 1977; Christian et al. 1983; HertZ \& HUey 1981; AdOlPH 1990; Rocha \& BERGallo 1990; GANDOLFI \& ROCHA 1998). Typically, those studies refer to the microclimatic qualities of a given microhabitat typc based on the air temperature and/or amount of direct insolation to which a lizard on its surface is exposed. In other words, they focus mainly on the lizard's gain of heat through direct solar radiation and through convection (but sec RAND \& RAND 1966; HEATWOLE 1970). However, there is a scarcity of data regarding qualities of lizard

1) Setor de Ecologia, IBRAG, Universidade do Estado do Rio de Janeiro. Rua São Francisco Xavier 524, Maracanã, 20550-015 Rio de Janeiro, Rio de Janeiro, Brasil.

2) Pós-Graduação em Ecologia, Departamento de Zoologia, Universidade Estadual de Campinas. Caixa Postal 6109, 13081-970 Campinas, São Paulo, Brasil.

3) Corresponding author. E-mail: cfdrocha@uerj.br 
microhabitats as direct heat sources (i.e. lizards would benef it from a particular microhabitat by absorbing heat from its surface by conduction). In this study, we present evidences that lizards (Scincidae: Mabuya) inhabiting open areas in southeastern Brazil may shift microhabitat preferences along the day, and that such shifts may be related to the thermal qualities of a particular microhabitat type (i.e. cactus) as a direct source of heat via conduction.

Two species of heliophylous scincid lizards, Mabuya agilis (Raddi, 1823) and Mabuya macrorhyncha Hoge, 1946, are common in coastal areas of southeastern Brazil, where they usually occur in sympatry (e.g. ARAÚJO 1994; ROCHA \& BERGALLO 1997; ROCHA 1998, 2000). The former species is mainly terrestrial, usually basking and foraging on the ground, while the latter is semiarboreal and usually basks on elevated perches, especially bromeliads (ROCHA \& VRCIBRADIC 1996; VRCIBRADIC \& ROCHA 1996). Field-active individuals of both species apparently regulate similar body temperatures (ROCHA \& VRCIBRADIC 1996). The two species are considerably abundant in the coastal sand-dune areas (restingas) of Grussaí and Praia das Neves, where the present study was conducted. In those two areas, both Mabuya species (including the ground-dwelling $M$. agilis) are not uncommonly found perched on cacti (mainly Cereus fernambucensis and Pilosocereus arrabidae), which are locally abundant. Since cactuses are filled with water, they are expected to cool off more slowly than surrounding air and to retain heat for relatively long periods, constituting a potential direct source of heat for thermoregulating lizards.

In the present study, we record the patterns of microhabitat use by those two lizard species along the day, and try to assess the importance of particular microhabitats (cacti and ground) as direct sources of heat for those animals.

\section{MATERIAL AND METHODS}

Fieldwork was carried out at two areas of "restinga" habitat in southeastern Brazil: Grussaí ( $21^{\circ} 44^{\prime} S$; $41^{\circ} 02$ 'W), in São João da Barra municipality, Rio de Janeiro state, and Praia das Neves (21 ${ }^{\circ} 15^{\prime} S$; $\left.40^{\circ} 58^{\prime} \mathrm{W}\right)$, in Presidente Kennedy municipality, Espírito Santo state. Restinga habitats occur in coastal areas of Brazil and are characterized by sandy, nutrient-poor soils and predominantly herbaceous and arbustive vegetation (SUGUIO \& TESSLER 1984); such open xeric habitats are part of the Atlantic Forest domain (EITEN 1992). Both species of Mabuya are considerably abundant in both areas.

Lizards were collected during November 1999 using air rifles and rubber bands. Collections were done daily from 07:00 to 18:00 and we promptly tried to capture cvery lizard sighted. Using a quick-reading cloacal thermometer, we measured each lizard's cloacal temperature $\left(T_{b}\right)$, as well as the air temperature $\left(T_{a}\right) l$ $\mathrm{cm}$ above the substrate at the lizard's initial position and the substrate temperature $\left(\mathrm{T}_{\mathrm{s}}\right.$ ), all to the nearest $0.2^{\circ} \mathrm{C}$. When more than 30 seconds elapsed between the first attempt to capture a lizard and its capture, temperature was discarded. The time at which each lizard was active when it was first sighted and the type of microhabitat it was using were also registered. At the laboratory, the animals were weighed (to the nearest $0.2 \mathrm{~g}$ ) using a Pesola ${ }^{\circledR}$ spring balance and their snout-vent length was measured using a caliper (to the nearest $0.1 \mathrm{~mm}$ ).

Revta bras. Zool. 19 (1): $77-83,2002$ 
We used the air and substrate temperatures taken in each microhabitat as a measure of the lizards' thermal environment. The differences in $\mathrm{T}_{\mathrm{b}}$ between the two species at each site were tested using a one-way analysis of variance (ANOVA) and also using an analysis of covariance (ANCOVA) using $\mathrm{T}_{\mathrm{a}}$ as covariate.

For the subsequent analyses, we used pooled data from both study sites for each species. Temperature data were divided in two groups for cach species: one comprising lizards collected on cacti and the other comprising lizards collected on the ground (for M. agilis) or on bromeliads (for M. macrorhyncha). Differences in mean $T_{b}, T_{a}$, and $T_{s}$ between the two groups were tested using ANOVA. For each group (and for M. macrorhyncha collected on cacti), the relationship between lizard $\mathrm{T}_{\mathrm{b}}$ and $\mathrm{T}_{\mathrm{a}}$ and $\mathrm{T}_{\mathrm{s}}$, respectively, were analysed by simple regression analyses (ZAR 1999). The relationship between lizard $\mathrm{T}_{\mathrm{b}}$ and both environmental temperatures simultaneously was estimated by multiple regression (ZAR 1999). Descriptive statistics are given as mean \pm 1 SD, unless otherwise stated.

\section{RESULTS}

Overall $\mathrm{T}_{\mathrm{b}}, \mathrm{T}_{\mathrm{a}}$ and $\mathrm{T}_{\mathrm{s}}$ of lizards (pooled data from both localities) averaged $32.0 \pm 2.6^{\circ} \mathrm{C}(\mathrm{n}=35), 28.0 \pm 2.4^{\circ} \mathrm{C}(\mathrm{n}=35)$ and $28.1 \pm 2.7^{\circ} \mathrm{C}(\mathrm{n}=30)$, respectively, for $M$. agilis and $30.0 \pm 3.3{ }^{\circ} \mathrm{C}(\mathrm{n}=21), 25.6 \pm 2.3{ }^{\circ} \mathrm{C}(\mathrm{n}=20)$ and $27.9 \pm 3.5^{\circ} \mathrm{C}(\mathrm{n}$ =16), respectively, for $M$. macrorhyncha.

Mean values and ranges of $\mathrm{T}_{\mathrm{b}}, \mathrm{T}_{\mathrm{a}}$, and $\mathrm{T}_{\mathrm{s}}$ for $M$. agilis collected on cacti and on the ground and for M. macrorhyncha collected on cacti and on bromeliads are given in table. I. Both $\mathrm{T}_{\mathrm{b}}$ and $\mathrm{T}_{\mathrm{a}}$ averaged higher (though not significantly so) for $M$. agilis collected on the ground compared to those collected on cacti, but mean $\mathrm{T}_{\mathrm{S}}$ of cacti was significantly higher than that of the ground (Tab. I). For M. macrorhyncha, there were no differences in $\mathrm{T}_{\mathrm{b}}$ and $\mathrm{T}_{\mathrm{a}}$ between lizards on cacti and those on bromeliads (Tab. I).

Table I. Mean values (with range in parentheses) of $T_{b}, T_{a}$, and $T_{s}$ for $M$. agilis collected on cacti and on the ground and for $M$. macrorhyncha collected on cacti and on bromeliads. $T_{s}$ values for bromeliads were not considered since they tended to be little or no different from respective $T_{a}$ s. F-values (from ANOVAs) are given on the bottom row, with an asterisk indicating values significant at 0.05 .

\begin{tabular}{|c|c|c|c|}
\hline Type of substrate & $T_{b}$ & $\mathrm{~T}_{\mathrm{a}}$ & $\mathrm{T}_{\mathrm{s}}$ \\
\hline \multicolumn{4}{|l|}{$M$. agilis } \\
\hline cactus $(n=10)$ & $\begin{array}{c}30.4 \pm 2.9^{\circ} \mathrm{C} \\
(27.0-35.2)\end{array}$ & $\begin{array}{l}26.8 \pm 2.3^{\circ} \mathrm{C} \\
(24.2-32.0)\end{array}$ & $\begin{array}{l}29.5 \pm 3.3^{\circ} \mathrm{C} \\
(25.0-36.4)\end{array}$ \\
\hline ground $(n=20)$ & $\begin{array}{l}32.3 \pm 2.3^{\circ} \mathrm{C} \\
(27.2-35.2)\end{array}$ & $\begin{array}{l}28.2 \pm 2.2^{\circ} \mathrm{C} \\
(24.4-32.6)\end{array}$ & $\begin{array}{l}27.3 \pm 2.9^{\circ} \mathrm{C} \\
(22.8-30.0)\end{array}$ \\
\hline$F$-value & 3.83 & 2.43 & $4.93^{*}$ \\
\hline \multicolumn{4}{|l|}{ M. macrorhyncha } \\
\hline cactus $(n=9)$ & $\begin{array}{l}30.0 \pm 3.5^{\circ} \mathrm{C} \\
(25.4-35.2)\end{array}$ & $\begin{array}{l}26.2 \pm 2.7^{\circ} \mathrm{C} \\
(23.4-30.6)\end{array}$ & $\begin{array}{l}28.6 \pm 3.9^{\circ} \mathrm{C} \\
(24.4-35.0)\end{array}$ \\
\hline bromeliad $(n=11)$ & $\begin{array}{l}29.7 \pm 3.3^{\circ} \mathrm{C} \\
(24.6-35.8)\end{array}$ & $\begin{array}{l}25.0 \pm 1.9^{\circ} \mathrm{C} \\
(21.6-27.6)\end{array}$ & - \\
\hline F-value & 0.06 & 1.19 & - \\
\hline
\end{tabular}


For $M$. agilis collected on cacti $(\mathrm{n}=10), T_{\mathrm{b}}$ was positively and significantly correlated with $\mathrm{T}_{a}(r=0.81 ; \mathrm{p}=0.005)$ and with $\mathrm{T}_{s}(\mathrm{r}=0.91 ; \mathrm{p}<0.001)$. The effect of both heat sources combined explained a significant part of the variation in $M$. agilis $\mathrm{T}_{\mathrm{b}}\left(\mathrm{R}^{2}=0.83 ; \mathrm{p}<0.005\right)$, but only $\mathrm{T}_{\mathrm{s}}$ explained an addittional portion of such variation $(p=0.029)$ after factoring out the eff ect of the other variable. For M. agilis collected on the ground $(n=20), T_{b}$ was significantly correlated with $T_{a}(r=0.56$; $p<0.05)$ but not with $T_{s}(r=0.32 ; p=0.17)$. The combined effect of both $T_{a}$ and $T_{s}$ significantly affected the variation in $T_{b}\left(R^{2}=0.32 ; p<0.05\right)$, but only $T_{a}$ explained an addittional portion of the variation in $\mathrm{T}_{b}(\mathrm{p}=0.035)$, when the other variable was factored out.

For M. macrorhyncha collected on cacti $(\mathrm{n}=9), \mathrm{T}_{\mathrm{b}}$ was positively and significantly correlated with $\mathrm{T}_{\mathrm{a}}(\mathrm{r}=0.84 ; \mathrm{p}=0.005)$ and $\mathrm{T}_{\mathrm{S}}(\mathrm{r}=0.84 ; \mathrm{p}<0.005)$, as well as with both heat sources combined $\left(R^{2}=0.72 ; p<0.05\right)$; however, neither $\mathrm{T}_{\mathrm{a}}$ nor $\mathrm{T}_{\mathrm{s}}$ showed an additive effect $(\mathrm{p}>0.5)$.

Data on microhabitat use frequencies by the two species during the morning (07:00-10:59 h), afternoon (11:00-15:59 h) and late afternoon (16:00-18:00 h) are presented in table II. Most (86.7\%) M. agilis collected before 11:00h werc on the ground, while $85.7 \%$ of those collected after $16: 00 \mathrm{~h}$ werc on cacti. For $M$. macrorhyncha there was no clear trend for the use of a particular microhabitat during each period. Mean $\mathrm{T}_{\mathrm{a}}$ (pooled data for both species at both sites) did not differ between morning $\left(28.0 \pm 2.9^{\circ} \mathrm{C}, \mathrm{n}=22\right)$ and afternoon $\left(26.9 \pm 2.5^{\circ} \mathrm{C}, \mathrm{n}=24\right)\left(\mathrm{F}_{1,44}\right.$ $=1.99 ; \mathrm{p}=0.17)$, nor between afternoon and late afternoon $\left(25.6 \pm 0.7^{\circ} \mathrm{C}, \mathrm{n}=9\right)$ $\left(F_{1,31}=2.43 ; p=0.13\right)$, but the difference was marginally significant between morning and and late afternoon $\left(\mathrm{F}_{1,25}=4.24 ; \mathrm{p}=0.05\right)$.

Table II. Frequency of use of each microhabitat type by $M$. agilisand $M$. macrorhyncha per time period at the restinga habitats of Grussai and Praia das Neves, Brazil (pooled data for both sites). Data include all animals collected, whether or not temperature data were taken.

\begin{tabular}{|c|c|c|c|c|c|c|c|c|}
\hline \multirow{2}{*}{ Microhabitat } & \multicolumn{4}{|c|}{ M. agilis } & \multicolumn{4}{|c|}{ M. macrorhyncha } \\
\hline & $0700-1100$ & $1100-1600$ & $1600-1800$ & Total & $0700-11001100$ & $0-1600$ & $1600-1800$ & Total \\
\hline Soil & 13 & 10 & 1 & 24 & - & 1 & - & 1 \\
\hline Cactus & 1 & 7 & 6 & 14 & 4 & 5 & 2 & 11 \\
\hline Bromeliad & 1 & - & - & 1 & 4 & 7 & 1 & 12 \\
\hline Other & - & - & - & - & - & 1 & - & 1 \\
\hline Totals & 15 & 17 & 7 & 39 & 8 & 14 & 3 & 25 \\
\hline
\end{tabular}

\section{DISCUSSION}

The data suggest that cacti are used as basking sites by both species, but that its importance in thermoregulation may differ between species. For M. agilis, it appears that gain of heat by conduction may be more important for lizards perching on cacti than for lizards on the ground. This is also suggested by the differcntial use of both types of substrate according to the daily period: the lizards appear to use 
cacti infrequently during the morning, but quite frequently during late afternoon. It is possible that $M$. agilis may bask on the ground during early morning, when environmental temperatures are low and surfaces of cactuses have not yet warmed up. By late morning, air temperatures may already be high enough to provide suitable heat sources for the lizards via convection, so that there may be no need to thermoregulate on cacti surfaces. As the afternoon progresses and air temperatures start to decrease, lizards begin to climb on cacti, by then already warm due to hours of exposure to solar radiation. Finally, by late afternoon, air temperatures have cooled off and lizards will presumably climb on cactuses to gain heat from direct contact with their surfaces, which have become warmer than the surrounding air (and presumably better meeting the thermal requirements of the skinks).

Heat gains through conduction via direct contact with the ground may have its importance diminished in $M$. agilis also because this lizard is usually found on the leaf litter rather than on open sand [of the 24 individuals collected on the ground, only five (20.8\%) were on open sand]. The litter layer prevents direct contact of the lizards with the sand, which may reach extremely high temperatures $\left(\mathrm{ca} .50-60^{\circ} \mathrm{C}\right.$ ) during the hotter hours of the day in restingas (ROCHA 1988; FIALHO 1990). Also, air temperatures during the hottest periods are usually higher at or near the ground compared to more elevated microsites (c.g. GEIGER 1965; PORTER et al. 1973; STEVENSON 1985; ADOLPH 1990). Thus, the primarily terrestrial M. agilis is presumably exposed to relatively high $\mathrm{T}_{\mathrm{a}}$ d during much of the day, without having to be in direct contact with the sand substrate. Unlike other lizards common in restingas (e.g. Tropidurus torquatus and Cnemidophorus spp.; e.g. BERGALLO \& ROCHA 1994; TEIXEIRA-FILHO et al. 1995, 1996), which are sometimes found on open sand away from shrub edge, $M$. agilis is a secretive species rarely leaving the edge of shrubs (VRCIBRADIC \& ROCHA 1996; personal observation). Thus, although those lizards could gain heat from contact with open sand af ter $\mathrm{T}_{\mathrm{a}}$ s have cooled off, that would leave them exposed; using the surface temperatures of cactuses, on the other hand, may have a similar effect without requiring the lizard to leave a patch of vegetation.

The importance of cacti surfaces as heat sources for thermoregulating $M$. macrorhyncha is less clearly suggested by our data. Unlike M. agilis, this species usually basks on elevated perches, especially bromeliads (VRCIBRADIC \& ROCHA 1996). Thus, being a naturally scansorial species, its climbing on cacti may not be particularly linked to heat gain by conduction. Also, our data suggest that $M$. macrorhyncha may perch indiscriminately on both bromeliads and cactuses during each period of the day. Nevertheless, our data for this species regarding the late afternoon period is too limited $(\mathrm{n}=3)$ and is insufficient to draw any conclusions about preferential microhabitat use during this period. Moreover, the additive effect of both $\mathrm{T}_{\mathrm{a}}$ and $\mathrm{T}_{\mathrm{s}}$ was more important than each of them alone in explaining the variation in $\mathrm{T}_{\mathrm{b}}$ for $M$. macrorhyncha individuals perching on cacti; this suggests that those lizards may actually benef it from the heat gain through contact with the surfaces of cactuses, even though they may use them primarily as basking sites (as they use bromeliad leaves). More data from specimens collected after 16:00 would probably help to settle this issuc. 
To sum up, our results suggest that microhabitat shift associated to thermoregulatory behavior may be employed by skinks (Mabuya spp.) in restinga areas where cacti are abundant, in order to take advantage of cactuses as heat sources. Such behavior appears more evident in the ground-dwelling $M$. agilis than in the scansorial M. macrorhyncha, but further data on both species (especially during late afternoon) are needed to test if they really differ in this aspect. It would be also interesting to compare $T_{a} s$ and $T_{s} s$ randomly taken at the surfaces of cacti, ground and bromeliad leaves during each period of the day, and also to compare those with the $T_{a} S$ and $T_{s} s$ experienced by members of both skink species taken in the field during the same day. The great abundance of both skinks and cacti makes the restingas of Grussaí and Praia das Neves excellent areas for such a study.

\begin{abstract}
ACKNOWLEDGEMENTS. This study is a portion of the results of the "Programa de Ecologia, Conservação e Manejo de Ecossistemas do Sudeste Brasileiro" and of the Southeastern Brazilian Vertebrate Ecology Project (Laboratory of Vertebrate Ecology), both of the Setor de Ecologia, Instituto de Biologia, Universidade do Estado do Rio de Janeiro. The study was partially supported by research grants from the Conselho Nacional de Desenvolvimento Científico e Tecnológico - CNPq to C.F.D.R. (processes \# 30081 9/94-3 and \# 461 970/00-7) and to D.V. (process \# 143607/98-7) and from the Fundação de Amparo à Pesquisa do Estado do Rio de Janeiro - FAPERJ (process E-26/170.385/97 - APQI) to the second author.
\end{abstract}

\title{
REFERENCES
}

AdoLPH, S.A. 1990. Influence of behavioral thermoregulation on microhabitat use by two Sceloporius lizards. Ecology 71: 315-327.

Araújo, A.F.B. 1994. Comunidades de lagartos brasileiros, p. 39-57. In: A.T. Bernardes; L.B. Nascimento \& G.A. Cotta (Eds). Herpetologia do Brasil I. Belo Horizonte, Pontifícia Universidade Católica de Minas Gerais, 134p.

Bergallo, H.G. \& C.F.D. Rocha. 1994. Spatial and trophic niche differentiation in two sympatric lizards

(Tropidurus torquatus and Cnemidophorus ocellifer) with different foraging tactics. Austr. Jour. Ecol. 19: 17-25.

Christian, K.; C.R. Tracy \& W.P. Porter. 1983. Seasonal shifts in body temperature and use of microhabitats by Galapagos land iguanas (Conolophus pallidus). Ecology 64: 463-468.

Eiten, G. 1992. Natural Brazilian vegetation types and their causes. An. Acad. Bras. Ciênc. 64 (Suppl. 1): $35-65$.

FIALHO, R.F. 1990. Seed dispersal by a lizard and a treef rog: effect of dispersal site on seed survivorship. Biotropica 22: 423-424.

GandolFi, S.M. \& C.F.D. Rocha. 1998. Orientation of thermoregulating Tropidurus torquatus (Sauria: Tropiduridae) on termite mounds in an openarea of south-eastern Brazil. Amphib.-Reptilia. Leiden, 19: $319-323$.

Geiger, R. 1965. The climate near the ground. Cambridge, Harvard University Press, 600p.

Heatwole, H. 1970. Thermal ecology of the desert dragon Amphibolurus inermis. Ecol. Mongr., Washington D.C., 40: 425-457.

Heatwole, H. \& J. Taylor. 1987. Ecology of Reptiles. Chipping Norton, Surrey Beatty \& Sons, 325p. HERTZ, P.E. \& R.B. HuEY. 1981. Compensation for altitudinal changes in the thermal environment by some Anolis lizards on Hispaniola. Ecology 62: 515-521.

Huey, R.B.; E.R. Pianka \& J.A. HorfmanN. 1977. Seasonal variation in thermorregulatory behavior and body temperature of diurnal Kalahari lizards. Ecology 58: 1066-1075.

Revta bras. Zool. 19 (1): 77 - 83, 2002 
Porter, W.P.; J.W. Mitchell; W.A. Beckman \& C.B. DewitT. 1973. Behavioral implications of mechanistic ecology. Oecologia 13: 1-54.

Rand, A.S. \& P.J. Rand. 1966. Aspects of the ecology of the iguanid lizard Tropidurus torquatus at Belém, Pará. Smithson. Misc. Coll. 151: 1-16.

Rocha, C.F.D. 1988. Ritmo de atividade e microclimatologia do habitat de Lioluemus lutzae (Sauria: Iguanidae). In: An. VI Semin. Reg. Ecol., São Carlos, p. 269-281.

-_— 1998. Composição e organização da comunidade de répteis da área de Mata Atlântica da região de Linhares, Espírito Santo. In: An. VIII Semin. Reg. Ecol., São Carlos, 2, p. 869-881.

-2000. Biogeografia de répteis de restingas: distribuição, ocorrência e endemismos, p. 99-116. In: F.A. Esteves \& L.D. LACERDA (Eds). Ecologia de Restingas e Lagoas Costeiras. Macaé, NUPEM/UFRJ, 394p.

Rocha, C.F.D. \& H.G. Bergallo. 1990. Thermal biology and flight distance of Tropidurus oreadicus (Sauria: lguanidae) in na area of Amazonian Brazil. Ecol. Ethol. Evol. 2: 263-268.

1997. Intercommunity variation in the distribution of abundance of dominant lizard species in restingahabitats. Ci. Cult. 49: 269-274.

Rocha, C.F.D. \& D. VRCibradic. 1996. Thermal biology of two sympatric skinks (Mabuy'a macrorhyncha and Mabuy'a agilis) in a Brazilian restinga habitat. Austr. Jour. Ecol. 21: 110-113.

STEVENSON, R.D. 1985. The relative importance of behavioral and physiological adjustments controlling body temperature in terrestrial ectotherms. Amer. Nat. 126: 362-386.

Suguio, T. \& M.G. Tessler. 1984. Planícies de cordões litorâneos quaternários do Brasil, p. 15-25. In: L.D. Lacerda: D.S.D. Araujo; R. Cerqueira \& B. TurcQ (Eds). Restingas: Origem, Estrutura, Processos. Niterói, Centro Editorial da Universidade Federal Fluminense, 475p.

Teixeira-Filho, P.: S. Ribas \& C.F.D. Rocha. 1995. Aspectos da ecologia termal e uso do habitat por Cnemidophortus ocellifer (Sauria, Teiidae) na restinga da Barra de Maricá, RJ, p. 155-165. In: F.A. Esteves (Ed). Oecologia Brasiliensis 1: Estrutura, Funcionamento e Manejo de Ecossistemas Brasileiros. Rio de Janeiro, Instituto de Biologia UFRJ, 597p.

TeIXeIRA-FILHO, P.; C.F.D. Rocha \& S. Ribas. 1996. Ecologia termal e uso do habitat por Tropidurus torquatus (Sauria: Tropiduridae) em uma área de restinga do sudeste do Brasil, p. 255-267. In: J.E. PÉFAur (Ed). Herpetologia Neotropical, Actas del II Congreso Latinoamericano de Herpetologia - II Volumen. Merida, Consejo de Publicaciones, Universidad de Los Andes, $4.51 \mathrm{p}$.

VRCIBRADIC, D. \& C.F.D. RochA. 1996. Ecological differences in tropical sympatric skinks (Mabuya macrorhyncha and Mabuya agilis) in southeastern Brazil. Jour. Herpetol. 30: 60-67.

ZAR, J.H. 1999. Biostatistical Analysis. Upper Saddle River, Prentice-Hall, 663p.

Recebido em 19.X.2000; aceito em 29.I.2002. 